\title{
EU FINANCIAL SERVICES POLICY SINCE 2007: CRISIS, RESPONSES AND PROSPECTS
}

\section{NICOLAS VÉRON}

This paper presents a holistic description and assessment of the European Union's financial services policy since the start of financial crisis in mid2007. The decade-long sequence is divided into four themes, in broadly chronological order: the initial reaction to the 2007-08 financial shock; subsequent initiatives framed by political developments at the EU and G20 level; the banking union from mid-2012; and more recent events centred on the United Kingdom vote to exit the EU (Brexit). The analysis identifies banking union as the watershed moment, and correspondingly assesses the EU policy response as mostly inadequate in the first half and mostly effective in the second half of the period covered. Recommendations for future reforms are made in the conclusion.

Key recommendations:

- Complete the task of breaking the bank-sovereign vicious circle in the euro area with a reform package that includes a European Deposit Insurance Scheme that equally protects all insured deposits, the introduction of sovereign concentration charges to reduce the home bias in banks' sovereign exposures, and the phasing out of national authorities' ability to ring-fence banks' capital and liquidity.

- Move towards a simpler, 'twin-peaks' architecture for financial supervision in the European Union with a strengthening of the governance and funding of the European Securities and Markets Authority and an expansion of its scope of direct responsibility over financial business conduct.

- A long-haul effort of further harmonisation in both banking and nonbank activities (banking union and capital markets union) to move closer to the vision of a single market for financial services, including areas such as accounting, auditing, insolvency legislation and investment taxation.

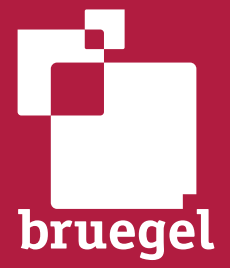

Nicolas Véron (nicolas.veron@bruegel.org) is a Senior Fellow at Bruegel and at the Peterson Institute for International Economics

This paper has been first published in Global Policy Volume 9, Supplement 1, June 2018, and available at https://onlinelibrary.wiley.com/doi/full/10.1111/1758-5899.12564. It is republished by Bruegel with permission. 


\section{Introduction}

This paper presents a holistic overview and assessment of the European Union (EU)'s financial services policy since the start of its financial crisis in mid-2007. Its emphasis is on public policy initiatives and developments at the European level, including those specific to the euro area.

Given this focus, national-level reactions in individual EU member states are not reviewed comprehensively, even those in countries with systemic relevance from an EU perspective such as the United Kingdom. Thus restricted, the scope of analysis still covers dozens of legislative texts, radical changes in the architecture of European financial regulatory institutions, and innumerable policy challenges. The underlying material is of staggering complexity, and the attempt made here is to see the forest for the trees. It implies that some policies that are important in their own right are omitted or only superficially mentioned.

Policy initiatives during that period were mostly motivated by the simultaneous crisis. As a consequence, the description of policy developments relies on an underlying analysis of the crisis itself. The European financial sector (which, much more than in the United States, is dominated by banks] entered a sequence of systemic fragility in mid-2007, at the same time as in the United States. But the analytical framework adopted here views the events of the last eleven years primarily as a home-grown European crisis, following years of dysfunctional financial supervision during the previous 'Great Moderation', rather than a consequence of US financial disorder. In this narrative, the US subprime crisis was not the main cause of subsequent turmoil in the European financial system, but only a trigger that revealed the extent of accumulated vulnerabilities. The causes of crisis on both sides of the Atlantic were fundamentally different. In the United States, the dominant driver was regulatory arbitrage by financial firms, enabled by complacent supervision especially of systemically important non-banks [subsequently reviled as a 'shadow banking system']. But the European problem was worse than supervisory neglect, as excessive risk-taking by banks was effectively encouraged by national authorities in a combination of financial repression and banking nationalism, as detailed below in Section 1. Similarly, in the analysis of developments in the euro area since 2010, Greece is not viewed as a major and central story in its own right, but rather as revealing of area-wide weaknesses.

Both the home-grown risk accumulation pre-crisis, and the structural fragilities revealed by the Greek tragedy, trace their origins in the mismatch between nationally-controlled banking systems on the one hand, and strong binding Europe-wide integration policies on the other hand, including the internal market, competition policy, and the euro itself. The tension between an essentially untouched banksovereign nexus at the national level and integrationist European policies has been referred to in recent years, not least by Europe's leaders since mid-2012, as the vicious circle between banks and sovereigns. This vicious circle has indeed been the central driver of financial deterioration and fragmentation in the euro area. Its highly structural nature in turn explains the painfully protracted pace of crisis management and resolution in the euro area, in contrast to the United States, other EU jurisdictions such as the UK and most Central European countries, or, inside the single market but outside of the EU, Iceland. Remarkably, the bank-sovereign vicious circle had been neglected in precrisis critiques of the euro area policy framework. It was first identified by staff at the International Monetary Fund (IMF), after the start of the crisis but long before the climax of Greek sovereign distress (Mody, 2009; Sgherri and Zoli, 2010), and gradually became mainstream in EU policy analysis and discourses as the crisis escalated (eg Darvas et al, 2011). 
The understanding of the crisis as home-grown and driven by the bank-sovereign vicious circle has increasingly been adopted by scholars (eg Smart, 2017; Raviv, 2017; Bayoumi, 2017). It is at odds with another narrative, which has tended to dominate the media and political discourse during most of the period covered. According to this more conventional narrative, a US-originated financial-sector tidal wave hit Europe as an external shock in 2007-09, was on its way to resolution by mid-2009, but was followed by a largely unrelated sequence of sovereign-debt crisis in the euro area starting with Greece in late 2009/early 2010 (eg Spiegel, 2014; Peet and La Guardia, 2014). But the conventional narrative of subprime crisis followed by Greek tragedy obscures the significance of euro-area banking sector fragility throughout the sequence. While superficially appealing to many, not least because it downplays the responsibility of policymakers in core euro-area countries and EU institutions, it is ultimately unhelpful to shed light on the more significant policy challenges.

The structure of the paper flows from its analytical framework, and combines chronological with thematic perspectives. Section 1 focuses on the pre-crisis build-up of risk and initial policy reactions between the summer of 2007 and the autumn of 2008 , when the turmoil associated with the Lehman Brothers bankruptcy opened a new phase in terms of crisis intensity and awareness. Section 2 examines developments from November 2008 to mid-2012, a period dominated by the rise in prominence of the Group of Twenty (G20) and Financial Stability Board (FSB) at the global level, and by dramatic financial fragmentation in the euro area despite tentative EU moves towards a more consistent financial regulatory architecture. Section 3 describes banking union as the most structurally significant policy initiative of the whole decade of crisis, from its inception in late June 2012 to the present. Section 4 reviews the policy agenda of the current European Commission, in place since late 2014, identifies remaining gaps in the resulting policy framework, including the implementation of banking union and consequences of the June-2016 British vote to exit the Union (Brexit). Section 5 concludes by summarising the resulting recommendations for next EU policy steps.

\section{Up to October 2008: Risk Build-Up and Early Responses}

The starting point of the financial crisis was a series of increasingly disorderly events that occurred at the end of July and beginning of August 2007, triggered by adverse developments in the US real estate market and especially its subprime segment. Two hedge funds backed by Bear Stearns failed, triggering high losses at IKB Industriebank, a fairly small bank in Düsseldorf, Germany. In the final days of July, the German authorities decided to recapitalise IKB and reimburse all its creditors (including the most subordinated ones), initiating a pattern of full bail-out of failing banks that became the European norm with very few exceptions until 2012 (see below). A few days later, Paris-based BNP Paribas suspending pricing and withdrawals for several of its mutual funds that had exposure to the US subprime property segment, and as a consequence, liquidity started to evaporate from large segments of asset-backed-securities markets. The European central Bank (ECB), followed by the US Federal Reserve, decided to provide extraordinary liquidity to those markets, opening a sequence of unconventional intervention by monetary policy authorities that has continued until now.

The roots of the crisis are to be found in the prior policy framework. The European Union in 2007 had a partly harmonised legislative framework for financial regulation, the result of various waves of initiatives, some of which dating back to the 1970s and the latest driven by the European Commission's Financial Services Action Plan of 1999. As a result, the Union had adopted directives covering banking (the first Capital Requirements Directive (CRD) of 2006, and earlier texts on supervisory frameworks], investment intermediaries (the Markets in Financial Investment Directive 
(MiFID) of 2004, superseding the earlier Investment Services Directive), mutual funds [three successive directives on Undertakings for the Collective Investment in transferable Securities, or UCITS), the supervision of financial conglomerates, the content of issuance prospectuses, the prevention of market abuse, and more. The 1999 legislative programme had been largely completed by mid-2007, with the exception of the directive on insurance supervision (known as Solvency II) for which the European Commission only published a proposal in July 2007, and which was adopted in 2009. As this enumeration suggests, the vast majority of applicable EU financial services legislation had taken the form of directives, which are framework laws requiring national transposition into the specific legal regime of each member state, thus typically stopping short of what has since become known as a 'single rulebook'. Regulations, which in this context refer to EU legislative acts that apply directly to market participants without a need for national transposition, were the exception prior to 2007. A significant such text was the International Accounting Standards Regulation of 2002, which mandated the use of International Financial Reporting Standards (IFRS), following an EU endorsement process, by all publicly listed companies, a major shift towards greater transparency and comparability of financial reporting whose implementation was completed in 2006.

Under this framework, member states retained considerable autonomy in setting financial regulatory policies. Furthermore, the implementation and enforcement of rules adopted at the national level (whether independently, or through the transposition of EU directives) was substantially the remit of national authorities, such as banking and insurance supervisors or securities regulators, with patterns of institutional architecture and approaches to financial oversight and regulatory enforcement differing widely from one member state to another. There had been attempts to foster better consistency of outcomes across member states, principally the creation of the three so-called Lamfalussy Committees in 2001-04 ${ }^{1}$, but the corresponding arrangements remained based on voluntary national commitments which were essentially unenforceable on a consistent basis. Simultaneously, the European Commission adopted a passive approach to its own role as enforcer of EU single market legislation, a body of law that includes the vast majority of financial regulatory directives and regulation. For example, the enforcement of corporate financial reporting using IFRS from 2006 onwards was left to national securities regulators or other national authorities (such as the Financial Reporting Council in the UK), with only a loose mechanism for comparing national practices at the European level in a subcommittee of CESR, the relevant Lamfalussy Committee.

Supervisory philosophies and practices could thus differ considerably among member states, leading to multiple opportunities for regulatory arbitrage within the European Union. For example, several German banks developed major exposures to the US property markets through legal entities in Ireland. These entities were technically supervised by the Irish authorities, but did not contribute to systemic risk in Ireland as long as the German banks guaranteed them. Conversely, they contributed to systemic risk in Germany but were not supervised from there. There appears to have been occasional attempts by the Irish authorities to alert their German counterparts about the corresponding risk concentrations, but with limited if any follow-up until mid-2007. EU coordination mechanisms such as CEBS were not equipped to identify such linkages, let alone to take action on them.

\footnotetext{
${ }^{1}$ These were the Committee of European Securities Regulators (CESR), established in 2001, and the Committee of European Banking Supervisors (CEBS) and Committee of European Insurance and Occupational Pensions Supervisors (CEIOPS), created in 2004. CESR in turn succeeded an earlier committee, known as the Forum of European Securities Commissions (FESCO), created in 1997.
} 
The combination between, on the one hand, national financial policy autonomy and, on the other hand, enforceable mechanisms to create a single EU financial market ${ }^{2}$, created a uniquely perverse set of incentives. First, most member states had longstanding traditions of using the domestic banking system as an instrument to channel various public policies, including the funding of the government itself, and the preferential direction of savings and credit towards favoured firms or sectors, a multifaceted cluster of practices to which economists loosely refer as 'financial repression'. Second, the market opening prompted by the EU single market and competition policies led most member states to give priority to the protection and/or promotion of their national banking 'champions' in the perceived pan-European contest for market dominance, a stance referred to as 'banking nationalism' with reference to broader patterns of economic nationalism, and often superseded prudential concerns (Véron, 2013). Taking advantage of the implicit guarantees inherent in this setting, many European banks expanded aggressively during the early 2000s, both in the Union and abroad, including by building up significant exposures in the United States and Asia. One example of such unchecked risk-taking was the expansion of ABN AMRO, a major Dutch bank, and its subsequent acquisition in 2007 through a hostile takeover by a consortium formed of the UK's Royal Bank of Scotland (RBS), Belgium's Fortis, and Spain's Santander. Santander quickly resold ABN AMRO's Italian subsidiary to Banca Monte dei Paschi di Siena (MPS) at a profit, and as a consequence the transaction was lucrative for them, but it otherwise played a material role in the subsequent failures and public rescues of RBS, Fortis, and MPS. The fact that all three banks were allowed to make this high-risk acquisition by their respective national overseers is representative of the attitude of supervisors in many member states, which effectively encouraged 'their' banks' expansion even in cases where their prudential mandate should have led them to curb it. This structural inadequacy of the supervisory framework was already observable at the time, even as it is more glaringly obvious with the benefit of hindsight.

After the initial shock of July/August 2007, the relevant authorities in Europe stayed in almost continuous denial of the seriousness of the situation and of the magnitude of the risks. The Bank of England went as far as refusing to provide liquidity to struggling banks in its jurisdiction, citing concerns about moral hazard, until this wholly unsuitable stance precipitated the collapse of Northern Rock in September 2007 and the first bank run in the UK since the 1860s. More pervasively, authorities in most member states painted the turmoil as temporary and entirely driven by US-based assets that were dubbed 'toxic', implying that the rest of the banks' balance sheets should be considered safe. As for the toxic assets themselves, there long lingered a pretence that the price fall of entire asset classes was mostly linked to liquidity constraints, exacerbated with fair value or 'mark-tomarket' accounting standards (which were duly, and entirely unfairly as it turned out, scapegoated for the market volatility], and would thus eventually rebound. At the EU level, there was no significant legislative response other than the delivery of pre-crisis projects, such as Solvency II as mentioned above. The commissioner in charge of financial services, Charlie McCreevy, had heralded a noninterventionist stance to financial regulation and was wrong-footed by the crisis. More generally, European leaders found it much more appealing to blame the United States and its market-driven, supposedly short-termist system for what was depicted as an exogeneous shock, than to reflect soberly on their own banking sectors' home-grown risks.

\footnotetext{
${ }^{2}$ In particular, the competition-policy arm of the European Commission, known as DG COMP, started in the late 1990 s to forcefully dismantle policy barriers against intra-EU cross-border mergers and acquisitions involving banks, as well as explicit government guarantees on specific banks.
} 
When a new cycle of financial dislocation started with renewed violence in September 2008, with the US nationalisation of Fannie Mae and Freddie Mac followed in short order by the bankruptcy of Lehman Brothers and the hasty public rescue of AIG, European policymakers were caught unaware. The initial reactions were almost entirely uncoordinated, such as the Irish government's rash decision to extend wide-ranging guarantees on its banking system on 30 September 2008, which other member states subsequently felt constrained to partly emulate in order to prevent a deposit flight to the perceived Irish safety. At the same time, the Fortis banking and insurance group had to be rescued by the governments of Belgium, Luxembourg and the Netherlands, initially in a joint manner then, following the breakdown of co-operation after a few days, along separate paths in each country. The perception rapidly spread that the chaos of ill-coordinated national interventions may quickly lead to a catastrophic financial unravelling. Eventually, euro-area leaders together with the British prime minister were able to announce joint principles for national rescues following a Sunday-evening summit in Paris on 12 0ctober 2008, after which the most disorderly phase of panic subsided somewhat. But the Paris plan, which was reaffirmed and endorsed by all member states of the European Union on 15 October, also carried the seeds of future financial fragmentation, since it entrenched the perception and reality that governments would reimburse all creditors of failing banks no matter how junior, as with IKB in July 2007, and that the corresponding guarantees and capital injections would be carried out entirely on each country's budget for banks in its jurisdiction. Thus, even as it generated a lull in the financial turmoil, the policy stance adopted by the European Union in mid-October 2008 made it near-inevitable that subsequent episodes of crisis would be driven by the bank-sovereign vicious circle and fragmentation of the European financial system across country boundaries, as indeed happened.

\section{From November 2008 to Mid-2012: EU Politics, the Larosière Report, the $\mathbf{G 2 0}$ and bank-sovereign contagion}

The intensification of the crisis in September-October 2008, and its extension to categories of risks that were clearly domestic to the European Union - such as the Irish and British real-estate assets borne on Irish banks' balance sheets - did not initially force a change in the political narrative according to which it was an inherently exogenous event, generated in the United States and a consequence of the market-based financial system there, increasingly referred to under the disquieting label of 'shadow banking'. In the then-dominant storytelling, Europeans (especially continental Europeans], banks, and singularly continental European banks were the victims of UScentric, Anglo-Saxon, market-based capitalist excesses. The spectacular developments around Fannie Mae, Freddie Mac, Lehman Brothers, AIG and other prominent US non-bank financial firms ostensibly led credence to this view.

As a consequence, the initial EU legislative response to the crisis was largely focused on issues which, with hindsight, appear peripheral at best, and, to the extent it addressed core issues (such as the quality of banks' capital, or cross-border consistency of supervisory approaches], far from sufficiently ambitious. In October 2008, the European Commission introduced proposals for amendments to the CRD of 2006, known as CRD II, applying more onerous capital requirements to asset securitisations (even though EU-based securitisations actually didn't give rise to credit quality problems during the crisis] and introducing 'supervisory colleges' for voluntary coordination of oversight, as well as a separate legislative proposal for limited harmonisation of deposit guarantee schemes following the Irish episode. In the following few months, the Commission aimed its guns at credit rating agencies, 
then widely described as crisis accelerators through ill-timed 'procyclical' downgrades (a charge which, with hindsight, appears rather pointless) ${ }^{3}$; at hedge funds and private equity investors, long targeted in European Parliament debates as dangerous 'locusts' but which actually proved surprisingly resilient in the crisis ${ }^{4}$; and once again at securitisation products and financial executives' remuneration, in yet another series of amendments to CRD known as CRD III ${ }^{5}$. Later on, and after Michel Barnier succeeded McCreevy in February 2010 as its member in charge of financial services, the Commission pursued other legislative efforts similarly driven for the most part by political motivations rather than substantial analysis, such as the attempt to create a European financial transaction $\operatorname{tax}(\mathrm{FTT})^{6}$; a confusingly designed, and ultimately low-impact, reform of the EU audit market ${ }^{\text {; }}$; and, as Commissioner Barnier's parting shot, a proposal for the separation of investment banking activities from retail credit ${ }^{8}$. The latter effort was eventually abandoned in 2017 , after having failed to draw sufficient consensus in the European Parliament; the FTT has not yet been approved by EU legislators at the time of writing.

Meanwhile, underlying banking-sector fragilities were left unresolved in most member states of the euro area, even as they were addressed comparatively more forcefully in the United Kingdom and some (though not all) Central and Eastern European member states ${ }^{9}$, as well as in Switzerland and Iceland. Following the successful execution of the 'stress tests' of the 19 largest US banks (Supervisory Capital Assessment Program] in the spring of 2009, member states asked CEBS to coordinate a multinational exercise of stress-testing covering "22 major European cross-border institutions representing $60 \%$ of the total assets of the $\varepsilon U$ banking sector on a consolidated basis", with aggregate findings published in early October $2009^{10}$. But, in stark contrast to the US template, there was no identification of the individual banks that were stress-tested, let alone bank-by-bank quantitative results, rendering the exercise practically meaningless ${ }^{11}$. As this initiative unsurprisingly failed to restore confidence, new waves of EU-wide stress tests were launched with results published in July 2010 and again in July 2011, this time with identification of individual banks and increasingly detailed disclosures of findings. The 2010 exercise was again coordinated by CEBS, and the one in 2011 by its successor the EBA (see below), but the underlying balance sheet assessments still remained fully in the hands of national authorities, with the EU level having neither the means nor a mandate to double-check their findings. Any credibility gained through additional transparency was ruined by subsequent developments, as banks that had been given a clean bill of health collapsed

\footnotetext{
${ }^{3}$ The Commission published three successive proposals for Credit Rating Agency (CRA) regulation, respectively in November 2008, June 2010, and November 2011; respectively enacted in November 2009, May 2011 and June 2013.

${ }^{4}$ The Alternative Investment Fund Managers (AIFM) Directive was proposed by the Commission in April 2009 and enacted in June 2011.

${ }^{5}$ CRD III was proposed by the Commission in September 2009 and enacted in November 2010. The three components of the CRD II legislative package had been enacted in April, July and September 2009 respectively.

${ }^{6}$ Proposal published in September 2011 by the European Commission, as an "enhanced cooperation" among willing member states. Unlike all other legislative texts mentioned in this section, this one is about tax policy not the EU internal market, and as such is covered by a different legislative process.

$?$ Directive and Regulation proposed by the Commission in November 2011, and enacted in April 2014.

8 Proposed regulation known as "banking structural reform", published by the European Commission in January 2014.

${ }^{9}$ Hungary, Latvia and Romania had received IMF assistance respectively in November 2008, December 2008, and May 2009.

${ }^{10}$ CEBS press release on the results of the EU-wide stress-testing exercise, 1 October 2009, accessed at http://www.eba.europa.eu/documents/10180/15977/CEBS-2009-180-Annex-2-\%28Press-release-from-CEBS\%29.pdf. . 11 In May 2009, CEBS had warned that "This is not a stress test to identify individual banks that may need recapitalisation, as the assessment of specific institutions' needs for recapitalisation remains a responsibility of national authorities" (CEBS's statement on stress testing exercise, 12 May 2009, accessed at http://www.eba.europa.eu/-/cebs-s-statement-onstress-testing-exercise).
} 
shortly afterwards, eg Allied Irish Banks in November 2010 or Spain's Bankia in April 2012. In the end, these stress tests only served to underline the dysfunction of the EU and especially euro-area supervisory framework, and the incentives for national banking supervisors to hide and deny problems in banks under their purview, generally driven by banking nationalism under the ever-lessconvincing excuse of forbearance to safeguard financial stability.

A more promising though still insufficiently ambitious initiative was the commissioning in late 2008 by European Commission President José Manuel Barroso of a report on EU financial regulation, which was promptly delivered by a high-powered expert group chaired by former French central banker (and former IMF Managing Director] Jacques de Larosière in February 2009. The Larosière Report (European Commission, 2009) articulated the vision of an EU financial 'single rulebook', implying fuller harmonisation of applicable rules and a shift from directives to regulations (in the latter's EU legislative sense). Concretely, it advocated the transformation of the three Lamfalussy Committees (CESR, CEBS and CEIOPS) into more authoritative 'European Supervisory Authorities', namely the European Securities and Markets Authority (ESMA), European Banking Authority (EBA), and European Insurance and Occupational Pensions Authority (EIOPA), respectively located in Paris, London and Frankfurt like their Committee predecessors. A European Systemic Risk Board (ESRB) was also recommended to monitor 'macro-prudential' issues and make recommendations accordingly, to be hosted by the ECB in Frankfurt. After member states endorsed these proposals in May 2009 and the corresponding legislation was eventually enacted in November 2010, the three ESAs were officially established on 1 January 2011 as agencies of the European Union, with a mandate that included the drafting of sublegislative 'technical standards' (akin to regulations issued by federal agencies in the US), with binding effect subject to endorsement (or modification) by the European Commission; authority for binding mediation of conflicts between national regulators; some scope for direct supervisory powers in narrowly-defined situations of emergency (which have never been invoked so far); and the theoretical possibility of direct supervisory oversight of specific market participants. The latter option has only been used so far for ESMA, which has become the direct and only supervisor of EU-based credit rating agencies in 2011 and of trade repositories in $2013^{12}$.

At the global level, a side effect of the climax of financial market turmoil in September-October 2008 was to generate a new consensus that financial regulatory matters required the attention of the world's most senior leaders. A combination of political motivations in France, Germany, the United Kingdom and the United States led to the innovation of convening summits of heads of state and government in the $G 20$ format, which until then had only been used at a more technical level of finance ministers and central bank governors. The first such $\mathrm{G} 20$ summit was held in Washington DC in mid-November 2008 and set an ambitious agenda for financial reform, which was translated into more specific actions over the two subsequent summit meetings, in London in April 2009 and in Pittsburgh in September 2009. The resulting G20 financial regulatory agenda kept evolving in the ensuing years. Some projects, such as the convergence between US accounting standards and IFRS, were quietly dropped after it became clear that they were making no progress. Others, such as the creation of consistent regimes and higher loss-absorbing capacity for the resolution of the world's largest banks, gained prominence over several years. The commitment to strengthen the minimum prudential standards applied to internationally active banks was rather quickly delivered upon by the Basel Committee on Banking Supervision (BCBS], with the essential elements of the new global accord known as Basel III published before the

\footnotetext{
${ }^{12}$ Note: the author is member of the board of one of the main trade repositories, namely the derivatives trade repository arm of DTCC (Depository Trust and Clearing Corporation).
} 
end of $2010^{13}$. In another key area of reform, global derivatives markets, common initiatives were agreed upon at the global level but with no corresponding global standard-setting, which led to largely inconsistent patterns of later implementation in individual jurisdictions.

The European Union, and particularly the European Commission, had been traditionally supportive of global financial standards, not least because they provided a powerful instrument to generate consensus among its own member states for projects of intra-EU regulatory harmonisation. The adoption of IFRS is a quintessential example of this dynamic: the Commission had failed to harmonise accounting standards, viewed as an important building block of the single market, through its own directives in the 1970s and 1980s; by contrast, its 'off-the-shelf adoption of IFRS was unanimously agreed by member states in 2002, and in turn boosted the credibility and use of IFRS in many other jurisdictions around the world. As a consequence, the Commission put considerable emphasis on the G20 process to frame its policy response to the still-developing crisis, with Commissioner Barnier repeatedly referring to the $\mathrm{G} 20$ agenda as his "road map"14. This motivated several EU legislative initiatives, including yet another round of CRD changes to (largely) incorporate Basel III into the EU legal order, this time also including a Regulation in the spirit of 'single rulebook', so Capital Requirements Regulation (CRR) and CRD IV, proposed in July 2011 and enacted in mid-2013; a comprehensive reform of EU derivatives markets known as the European Market Infrastructure Regulation (EMIR), proposed by the European Commission in October 2011 and enacted in July 2012; and, following a protracted period of consultation, the adoption of a bank resolution regime largely modelled on the US template and enshrined in the Bank Recovery and Resolution Directive (BRRD), first proposed by the Commission in early June 2012, and enacted in May 2014 with significant amendments introduced in the new context of banking union (see next section).

As previously highlighted, this intense legislative activity on financial regulation occurred while the core problem of system-wide banking fragility was left essentially unaddressed. Worse, the extensive national public guarantees of the banking sector soon started threatening the creditworthiness of an increasing number of euro-area member states, especially following the revelation of worse-thanexpected fiscal deficits in Greece in late 2009 (and even though these were essentially unrelated to banking-sector problems] and the subsequent joint signalling by France and Germany that failing member states may have to default on their sovereign debt, most explicitly with the Deauville declaration of mid-October 2010. As a consequence, not only did Greece lose sovereign debt market access, but other member states that did not share Greece's fiscal incontinence had to require financial assistance as well, including Ireland in November 2010, Portugal in May 2011, and Spain in July 2012 (even though Spain never lost sovereign debt market access). Italy also came under severe market pressure from mid-2011, and even French banks partly lost access to dollar funding in August and September 2011. Meanwhile, and unlike in the United States, almost all bank rescues that were carried out in the European Union included a full reimbursement or guarantee by the relevant governments of bank creditors no matter how subordinated, the only significant exceptions being in Ireland (were subordinated creditors incurred losses but senior ones were almost entirely reimbursed, at the insistence of the ECB and European Commission and against the advice of the IMF] and in Denmark (which had established a functioning framework for burden-sharing by bank creditors comparatively early on, following the publicly-funded rescue of Roskilde Bank in August 2008). By the end of 2011, the combination of banking system fragility with the increasingly exacerbated banksovereign vicious circle started to threaten the very integrity of the euro area, with investors

\footnotetext{
${ }^{13}$ Later on, the BCBS added more dimensions to the Basel III accord, which was fully finalised in December 2017.

${ }^{14}$ For example, Ben Hall, 'Barnier vows to abide by world code of regulation', Financial Times, 5 December 2009.
} 
increasingly internalising the possibility of a break-up which thus appeared on its way to become a self-fulfilling prophecy. Greece defaulted on its sovereign debt in March 2012, too late for this to resolve its debt sustainability challenge, and immediately required a further round of massive financial assistance from the euro area and the IMF. By the spring of 2012, it had become glaringly obvious that the course of euro area policy had become unsustainable.

\section{Banking union}

The idea of shifting the main instruments of banking sector policy from the national to the European level long predates the financial crisis. On the face of it, this shift, now widely referred to as banking union, is a logical consequence of the European Union's longstanding policy of creating a single market for banking services. But because of the significance of financial repression and banking nationalism in most member states, banking sector policy had remained predominantly national even after the shock of the 2007-08 financial crisis, as described above. It took the severe financial contagion, fragmentation and dislocation of 2011 and early 2012 to force an acceptance by political leaders of the necessity of banking union, and even then, only in a limited form and covering only the euro area. Still, the inception of banking union is increasingly seen as the most structurally significant EU policy initiative in the past decade, and the summit of June 28-29, 2012 when it was decided, as the most significant in the long sequence of European crisis summits (eg Draghi, 2013; Van Rompuy, 2014; Hollande, 2016; Smart, 2017).

The decision of June 29, 2012 was a recognition by euro-area leaders of the need to radically change investors' expectations about the area by taking an action that would be viewed as a credible commitment to hang together. By that time, the bank-sovereign vicious circle was generally understood to be at the core of the current phase of crisis. Action on the fiscal side, eg by pooling the ability to raise tax, make expenditures, and/or issue debt securities ['fiscal union'], had been ruled out as politically unfeasible, at least in the short term and given widespread negative perceptions about the fiscal behaviour of the Greek and other governments. That left banking union as the least unpalatable option. It had been advocated with increasing specificity by a growing range of scholars and individual policymakers in the previous months, including the IMF with a high degree of urgency and specificity (Lagarde, 2012) and, in less precise words or with a potentially longer time horizon, by the respective presidents of the ECB, of the European Commission, and of the European Council (De Rynck, 2015; Véron, 2016).

The declaration of euro-area leaders on June 29 started with the sentence "We affirm that it is imperative to break the vicious circle between banks and sovereign", followed by the decision to set up a 'single supervisory mechanism' (SSM) on the basis of article 127 (6) of the Treaty on the Functioning of the European Union, which implied that it would be entrusted to the ECB. The statement added that the European Stability Mechanism (ESM) would be empowered to make direct bank recapitalisations "[w] hen an effective single supervisory mechanism is established". In the run-up to the summit, the possibility of ESM direct recapitalisation of banks had been advocated by various parties, including the French government and the IMF, as the 'game-changer' that the situation required. The German government in turn had insisted on the SSM as a prerequisite, to ensure that future recapitalisations would be based on a neutral and reliable assessment of weak banks' true capital needs. In the weeks and months that followed the June summit, and on the basis of the political shift towards cohesiveness that it represented, the ECB was able to make its own expectations-shifting announcement of "whatever-it-takes" intervention "to preserve the euro", in the form of the Outright 
Monetary Transactions (OMT) programme. This opened a long cycle of return of euro-area sovereign debt markets back to sustainable levels. Meanwhile, and partly since the OMT had reduced the pressure to act, the German and other governments reversed their acceptance of ESM direct bank recapitalisation, and instead promoted a stricter and earlier implementation of 'bail-in' (ie loss-sharing by a failing bank's creditors] as a guiding principle of future banking crisis management.

The early implementation of banking union reflected these compromises and shifts. As had been signalled on 29 June, the SSM (also known as European Banking Supervision) represented the first building block, and the one on which the others would rest. A legislative proposal for the SSM Regulation was published by the European Commission in September 2012, swiftly and unanimously adopted by the Council in December, and (after some back-and-forth with the European Parliament and in the German domestic debate, not coincidentally in an election year) enacted in October 2013. The shift from ESM direct bank recapitalisation towards fostering stricter bail-in led to significant amendments in the ongoing legislative discussion of the BRRD, especially the decision in late 2013 to move the effective date for mandatory senior debt bail-in in bank resolution from the Commission's initial proposal of 2018 forward to 1 January $2016^{15}$.

In another major policy step, the political leaders agreed in December 2012 that this shift might only work if resolution authority was also pooled at the euro-area level, at least for significant banks. As a result, the European Commission proposed a regulation establishing a Single Resolution Mechanism (SRM) in July 2013, and it was enacted in July 2014. The SRM is centred on the Single Resolution Board (SRB), a newly created EU agency based in Brussels that would propose decisions to resolve (or orderly liquidate) banks that the ECB (or the SRB itself) deems "failing or likely to fail" in accordance with the BRRD, with final decisions relying on a somewhat complex procedure that also involves the European Commission and the Council of the European Union. The SRB also manages a Single Resolution Fund [SRF], in fact a collection of national funds and a euro-area one (referred to as national and mutualised 'compartments'] due for eventual merger into one fund by 2024, based on collection by the SRB and national authorities of a levy on individual banks. As for the ESM, its guidelines on direct bank recapitalisation were finally approved by the ESM's Board of Governors in December 2014, but include conditions so restrictive that it is unlikely that the instrument will ever be used unless the guidelines are revised.

This framework is now effectively in place, and its implementation has been broadly effective so far, though not without qualifications. The SSM (ie the ECB through its newly established bank supervisory arm) took over prudential authority over all banks in the euro area on 4 November $2014^{16}$. The SRB was established in 2015 and has taken over resolution authority over significant banks from its national counterparts on 1 January 2016. The SSM appears to have had a significant positive impact in terms of restoring adequate capital levels in most of the banks it supervises directly (Schoenmaker and Véron, 2016). This task appears almost complete at the time of writing, even though much restructuring is still needed to bring the euro-area banking sector fully back to soundness. The SRM appears not to have been fully operational in 2016 and early 2017, but there are indications of gradual

\footnotetext{
15 The BRRD was eventually enacted in May 2014.

${ }^{16}$ More precisely, the ECB is the sole prudential supervisor of all euro-area banks above certain thresholds of significance, including all with more than EUR 30 billion in total assets. As of November 2016, there were 126 such 'significant institutions' representing about four-fifths of the area's total banking assets. The 3,000-odd smaller banks or 'less significant institutions' remain supervised on a day-to-day basis by the pre-existing national authorities, but under binding oversight by the ECB which has sole authority to grant or withdraw their banking licenses and to review changes of ownership or of management.
} 
improvement [ECA, 2017]. It passed its first operational test in early June 2017 with the orderly resolution of Banco Popular, Spain's sixth-largest bank whose operations were swiftly taken over by Banco Santander, even though this case has also given rise to multiple lawsuits. The BRRD principle of senior bond bail-in, however, has not yet been fully established, and was circumvented by the Italian authorities in the liquidation of two medium-sized banks, Banca Popolare di Vicenza and Veneto Banca, also in June 2017. These are only early steps in what promises to be a long sequence of discovery before the new European model of bank crisis management and resolution achieves a high degree of consistency and predictability.

\section{The Juncker Commission and Brexit}

Following the frantic legislative activity during Commissioner Barnier's tenure (early 2010 to late 2014), the arrival of a new European Commission in November 2014 marked a change of pace and atmosphere in terms of financial regulatory reforms. The euro-area crisis had become less intense, with early indications that the introduction of European banking supervision would eventually put an end to banking-sector fragility as intended ${ }^{17}$; there was a widespread recognition, unsurprisingly encouraged by the financial industry, that the massive amount of legislation of the previous few years would need to be digested, and inconsistencies or unintended consequences identified, before major new initiatives should be undertaken; and perhaps most importantly, the prospect of the UK referendum on EU membership, announced by British prime minister David Cameron in January 2013 and made more tangible in the run-up to the UK general election of May 2015, led the new Commission president Jean-Claude Juncker to focus on a financial services agenda that could be viewed from London in a positive light.

With this motivation, President Juncker made two significant choices early on. First, in the policy platform he presented to the European Parliament for his confirmation vote, just after stating his commitment to the banking union project, he announced: "we should complement the new European rules for banks with a Capital Markets Union. To improve the financing of our economy, we should further develop and integrate capital markets. This would cut the cost of raising capital, notably for SMEs [small-and medium-sized enterprises], and help reduce our very high dependence on bank funding. This would also increase the attractiveness of Europe as a place to invest" (Juncker, 2014). While the label 'capital markets union' echoed banking union, the emphasis on markets was a signal of attention to the City of London, and the Commission immediately made clear that the project would be tailored to British preferences, and specifically that a centralisation of authority over market supervision in the hands of EU institutions would be categorically ruled out (Ringe, 2015). Second, Juncker granted the portfolio of financial services to the British member of the European Commission, Jonathan Hill, a notable expression of goodwill especially as it followed a less-than-friendly attitude of the UK government in the context of Juncker's own appointment ${ }^{18}$.

\footnotetext{
17 In the course of 2014 the ECB coordinated a system-wide 'comprehensive assessment' of 130 banking groups which, unlike the ill-fated previous rounds of EU-wide stress-testing, included intrusive asset quality assessments which national supervisors didn't fully control. The results were published in late October, days before the transfer of supervisory authority to the ECB on 4 November. While far from perfect, the comprehensive assessment reassured investors that the ECB would be a more rigorous supervisor than the national authorities it took over from.

${ }^{18}$ See eg lan Traynor and Rowena Mason, 'Britain handed financial services portfolio in European commission', The Guardian, 10 September 2014.
} 
As it turned out, the UK referendum campaign led the European Commission to turn capital markets union, at least until June 2016, into a mostly rhetorical project rather than a fully-fledged policy endeavour. New legislation was proposed only on issues of limited practical impact, to facilitate securitisation and reduce the administrative burden of securities issuance prospectuses, but most of the effort was to spread the message of how much the European Union had to gain from more developed capital markets (which would indeed benefit the entire EU economy, but also the City of London to an even greater extent), and the more potentially contentious issues were delayed to until after the referendum vote. These included the European Commission's proposal to partly harmonise insolvency law among EU member states, which was published in November 2016, on which the legislative process is ongoing.

Meanwhile, the UK's vote on 23 June 2016 to leave the European Union has altered the EU policy environment. Commissioner Hill promptly resigned, and President Juncker entrusted the financialservices portfolios to Valdis Dombrovskis, a Vice President of the European Commission who was already involved in economic and monetary affairs. It is too early at the time of writing to identify how Brexit, assuming it happens in March 2019 as announced, will structurally impact the financial services policy of the remaining Union of 27 member states (or EU27). Most of the public attention in the months following the referendum has focused on the future status of the UK, inside or outside the internal (or single) market that frames most EU financial regulatory policy, and how it might be affected by bilateral arrangements with the EU27 and other jurisdictions. In her letter to formally announce Brexit, the UK prime minister has called for "a bold and ambitious Free Trade Agreement between the United Kingdom and the European Union (...) that (...) covers sectors crucial to our linked economies such as financial services and network industries" (May 2017). The experience of financial-services chapters in past free trade negotiations, however, suggests that the potential to enshrine significant financial regulatory provisions in that vehicle is limited at best (see eg Gelpern, 2016). The future drivers of the relationship as regards financial services policy are altogether more likely to be the domestic legislative and regulatory changes adopted in future by the UK and the EU2? in their respective jurisdictions, and bilateral voluntary arrangements (eg memorandums of understanding) between relevant authorities on both sides of the Channel (or the Irish Sea), as opposed to any binding future UK-EU free trade agreement, even assuming such an agreement is eventually reached.

The reason why Brexit justifies a rethinking of EU27 financial services policies is because London has gained a unique position in the EU(28) financial system, dwarfing any other European financial centre for wholesale market activity. The EU27 is not currently well equipped for the proper oversight of a massive inflow of such activity onto its jurisdiction, especially for supervisory functions other than the prudential authority of the ECB over banks. These functions include most conduct-of-business oversight of financial markets, including the supervision of trading platforms, enforcement of regulations against market abuse, review of listed companies' financial disclosures, control of nonbank financial intermediaries, as well as the prudential supervision of clearing houses (also known as central counterparties or CCPs], some of which have become critically important institutions from a financial stability perspective following the $\mathrm{G} 20$ reforms of derivatives markets. Given the concentration of wholesale activity in London, the European Union has practically relied on the experienced UK authorities for the bulk of these responsibilities in recent times. But with the prospect of the UK leaving the single market, the EU27 needs to decide on which principles it may build up alternative oversight capacity (Sapir et al., 2017). At the time of writing, the European Commission 
appears to favour an expansion of the role of ESMA, both generally (European Commission, 2017) and specifically in the case of CCPs ${ }^{19}$.

\section{Conclusion: achievements, missing pieces and next steps}

The European Union's financial services policy since the crisis started in 2007 has involved both great shortcomings and great achievements. As this paper has argued, the turmoil has revealed massive supervisory failures which in turn stemmed largely from an inadequate architecture for financial supervision. The response to the core problem of banking sector fragility has been disastrously slow, particularly in the euro area, with the first half-decade of crisis (mid-2007 to mid-2012) essentially wasted with dilatory measures. After the breakthrough inception of banking union in mid-2012, the process of repair and restructuring has been painfully protracted. Even so, the establishment of the SSM, and to a lesser extent also those of the ESAs and SRM, represent radical change, with already significant and positive impact on the structures of the European financial sector. This structural change has been implemented remarkably quickly, and is more comprehensive than any comparable episode in the long history of banking sector policy integration in the United States (Gelpern and Véron, 2018). The aim of a single financial rulebook remains largely aspirational, but significant progress has been made in its direction, for example in bank capital and derivatives regulation. The future impact of these reforms is likely to be even more visible yet, particularly if cross-border bank acquisitions pick up in the next few years. Overall, a measure of guarded optimism is in order as to the European Union's ability to face the next challenges as its financial system continues to evolve.

The most obvious current piece of unfinished work is the banking union. "Completing banking union", an expression frequently used by euro-area policymakers at the time of writing, can mean at least three different things depending of context. First, it could mean delivering on the stated aim of banking union, namely to break the bank-sovereign vicious circle: that could be called a 'no-doom-loop banking union'. Second, it could imply a genuine single market in banking services, in which a bank's business is entirely indifferent to where it is located and headquartered: that would be a 'single-market banking union', an even more ambitious vision that the previous one. One aspect of it would be to extend the geographical scope of the banking union, or banking union area, to the full membership of the European Union.

A 'no-doom-loop banking union' is within reach at the time of writing, though by no means a foregone conclusion. The bank-sovereign vicious circle has already been mitigated by the early implementation of the SSM, SRM, and BRRD, but it remains far from broken altogether. Beyond the ECB's ongoing efforts to restore all euro-area banks' soundness and thus allow confidence to return to the sector, more legislative reforms are needed to fulfil the promise of banking union and make it into a resilient and consistent policy framework. One of these would be the transfer of deposit insurance from the national to the European level, occasionally referred to as a 'third pillar' of banking union alongside the SSM and SRM. The European Commission has published in November 2015 a well-drafted proposal for a European Deposit Insurance Scheme (EDIS), but there has been little progress in the legislative discussion since. In turn, an effective design for EDIS requires regulatory safeguards against the temptation of member states to use 'their' banks' facilitated access to deposits in order to get preferential funding for themselves. Thus, a natural complement to EDIS would be the introduction of

\footnotetext{
${ }^{19}$ The European Commission published a legislative proposal to reform the supervision of CCPs in June 2017, and a separate proposal to overhaul ESMA (together with the EBA and EIOPA) in September 2017.
} 
sovereign concentration charges [SCCs], namely a regulatory instrument to disincentivise concentrated euro-area sovereign exposures of euro-area banks. There is an increasing recognition that the combination of well-designed EDIS and SCCs (together with the acknowledgement of a backstop role of the ESM to both the SRF and EDIS) would substantially achieve the objective of breaking the bank-sovereign vicious circle and could be secured as early at 2018, even though the legislative and implementation process would inevitably take a number of additional years (BénassyQuéré et al, 2018).

A 'single-market banking union' is not so readily available. Unlike, say, most goods manufacturers, banks are dependent for their business model from social and policy frameworks that remain highly divergent from one country to another within the euro area. National idiosyncrasies in such wide policy areas as accounting and auditing, insolvency law, housing finance, pension systems, and of course taxation will keep tilting the competitive playing field for many years and possibly decades to come. The same observation can be made about the European Commission's project of a Capital Markets Union. A natural first step for the latter, as observed at the end of the previous section, would be to build up the regulatory and supervisory authority of ESMA, but this can only be a first step. As for the banking union's geographical scope, the 'close cooperation' procedure set out in the SSM Regulation allows a non-euro-area country to join on a voluntary basis. Even though no member state has done that so far, it is not impossible that Denmark, Sweden, and some Central European countries might opt for close cooperation in the future.

Another area that has been largely neglected during the years of crisis is that of financial business conduct, including consumer financial protection at the retail level. A recent stark remark by an Irish central bank official that "consumer protection went into hibernation during the financial crisis" 20 is representative of the greater priority that has been accorded, perhaps inevitably, to financial stability issues. But the two mandates, of business conduct and prudential supervision, are complementary even though it is generally advisable to entrust them to separate institutions. This linkage was starkly illustrated by the difficulty to close Italian banks that had sold their own securities to their retail clients, a systemic failure of financial consumer protection, and in a different context, by questions about the effectiveness of banking union raised following the liquidation of Latvian bank ABLV in February 2018 following money laundering allegations. In the wake of the above recommendations on capital markets union, a gradual accrual of business conduct supervisory tasks to ESMA would be desirable, even though a fully-fledged 'twin-peaks' architecture for EU financial supervision, ie one with a clear distinction between conduct and prudential supervision at the European level, can only be envisaged in the long term (Schoenmaker and Véron, 2017).

Of course, new issues will also emerge that require a financial regulatory response. If only because of new financial technologies, the European Union will constantly need to adapt its regulatory and supervisory tools in the years ahead. Finally, an area of lingering inconsistency in EU financial regulatory policy is the Union's shifting attitude to global standards. As has been mentioned in section 2, the European Union has often championed global financial regulatory standards in its rhetoric, and has leveraged them in the past to foster consensus among member states. But in recent years, the Union has increasingly tended to deviate from global standards in the formulation of its regulatory policies. This has been most evident in the area of capital requirements, where the European Union was the only jurisdiction to be found 'materially non-compliant' with the Basel III Accord, judging from the Basel Committee's own regulatory consistency assessment programme

\footnotetext{
${ }^{20}$ Laura Noonan, 'Central bank needs beefing up for expansion after hibernation', Financial Times, 31 January 2018.
} 
(BCBS, 2014). Particularly in the global context created by the Trump administration in the United States, the European Union has a strategic interest in the credibility and authoritativeness of global financial regulatory standard-setting, and should support it through an unambiguous and effective commitment to compliance.

\section{References}

Bayoumi, Tamim (2017) Unfinished Business: The Unexplored Causes of the Financial Crisis and the Lessons Yet to be Learned, Yale University Press

BCBS [2014] 'Regulatory Consistency Assessment Programme (RCAP] Assessment of Basel III Regulations: European Union', Basel Committee on Banking Supervision, Bank for International Settlements, December

Bénassy-Quéré, Agnès, Markus Brunnermeier, Henrik Enderlein, Emmanuel Farhi, Marcel Fratzscher, Clemens Fuest, Pierre-Olivier Gourinchas, Philippe Martin, Jean Pisani-Ferry, Hélène Rey, Isabel Schnabel, Nicolas Véron, Beatrice Weder di Mauro and Jeromin Zettelmeyer (2018) 'Reconciling risk sharing with market discipline: A constructive approach to euro area reform', CEPR Policy Insight No.91, London: Centre for European Policy Reform, January

Darvas, Zsolt, Jean Pisani-Ferry and André Sapir (2011) 'A comprehensive approach to the euro-area debt crisis', Policy Brief 2011/02, Bruegel

De Rynck, Stefaan (2015) 'Banking on a union: the politics of changing eurozone banking supervision', Journal of European Public Policy, March

Draghi, Mario (2013) 'Stable Euro, Strong Europe', speech at the Wirtschaftstag 2013, Berlin, 25 June

ECA [2017] 'Single Resolution Board: Work on a challenging Banking Union task started, but still a long way to go', Special Report No. 23/2017, Luxembourg: European Court of Auditors

European Commission (2009) Report of the High-Level Group on Financial Supervision in the $E U$ chaired by Jacques de Larosière, February

European Commission (2017) 'Communication on the Mid-Term Review of the Capital Markets Union Action Plan', COM[2017) 292, 8 June

Gelpern, Anna (2016] 'Financial Services', in Assessing the Trans-Pacific Partnership: Market Access and Sectoral Issues, PIIE Briefing 16-1, Peterson Institute for International Economics, February

Gelpern, Anna, and Nicolas Véron (2018) 'The Long Road to a US Banking Union: Lessons for Europe', in Jacob Funk Kirkegaard and Adam S. Posen (eds) Lessons for EU Integration from US History, Peterson Institute for International Economics

Hollande, François (2016) 'Discours à l'occasion de la celebration des 20 ans de l'Institut Jacques Delors', Paris, 6 October

Juncker, Jean-Claude (2014] 'A New Start for Europe: My Agenda for Jobs, Growth, Fairness and Democratic Change', opening statement in the European Parliament session, Strasbourg, 15 July Lagarde, Christine (2012) 'Global Challenges in 2012', speech in Berlin, 23 January 
May, Theresa (2017) letter to President of the European Council Donald Tusk, 29 March

Mody, Ashoka (2009) 'From Bear Stearns to Anglo Irish: How Eurozone Sovereign Spreads Related to Financial Sector Vulnerability', International Monetary Fund Working Paper WP/09/108

Peet, John, and Anton La Guardia (2014) Unhappy Union: How the euro crisis - and Europe - can be fixed, London: The Economist, June

Raviv, Or (2017) 'Europe's Mea Culpa: A Global Economy Gone Mad or a Crisis of Our Own Making?' Global Policy 8:2

Ringe, Wolf-Georg (2015) 'Capital Markets Union for Europe: A Political Message to the UK', Oxford Legal Studies Research Paper 26/2015

Sapir, André, Dirk Schoenmaker and Nicolas Véron (2017) 'Making the Best of Brexit for the EU27 Financial System', Policy Brief 17-8, Peterson Institute for International Economics

Schoenmaker, Dirk, and Nicolas Véron (eds) (2016) European Banking Supervision: the first eighteen months, Blueprint 25, Bruegel

Schoenmaker, Dirk, and Nicolas Véron (2017) 'A 'twin peaks' vision for Europe', Policy Contribution 30/2017, Bruegel

Sgherri, Silvia, and Edda Zoli (2010) 'Euro Area Sovereign Risk During the Crisis', International Monetary Fund Working Paper WP/09/222

Smart, Christopher [2017] 'The Financial Education of the Eurozone', Mossavar-Rahmani Center for Business and Government Associate Working Paper Series No. 69, Cambridge MA: Harvard Kennedy School

Spiegel, Peter [2014] How the Euro Was Saved, Financial Times/Pearson Education

Van Rompuy, Herman (2014) 'Speech on the occasion of the inauguration of the Single Supervisory Mechanism, European Central Bank', Frankfurt, 20 November

Véron, Nicolas (2013) 'Banking Nationalism and the European Crisis', speech to the European Private Equity and Venture Capital Association (EVCA) Annual Conference in Istanbul, June

Véron, Nicolas [2016] 'The IMF's Role in the Euro Area Crisis: Financial Sector Aspects', IEO Background Paper BP/16-02/10, Washington DC: Independent Evaluation Office of the International Monetary Fund 
(c) Bruegel 2018. All rights reserved. Short sections, not to exceed two paragraphs, may be quoted in the original language without explicit permission provided that the source is acknowledged. Opinions expressed in this publication are those of the author[s] alone.

Bruegel, Rue de la Charité 33, B-1210 Brussels

(+32) 22274210

info@bruegel.org

www.bruegel.org 